\title{
熱源システムの最適運転による室温湿度変動とそのシステム構成が 最適化効果に与える影響
}

一夏季代表日における中規模事務所ビルの複合熱源蓄熱システムを対象とした基礎的検討一

\section{INDOOR AIR TEMPERATURE AND HUMIDITY FLUCTUATION UNDER OPTIMAL OPERATION OF HEAT SOURCE SYSTEM AND EFFECT OF SYSTEM COMPOSITION ON THE OPTIMIZATION RESULTS}

-Fundamental study on hybrid energy source system with thermal storage tank of middle scale office building on a summer day-

\author{
赤司泰義*1, 渡辺俊行*2, 龍 有二*3, 松尾 陽*4, 高橋 淳一*5 \\ Yasunori AKASHI, Toshiyuki WATANABE, Yuji RYU, \\ Yoh MATSUO and Jun-ichi TAKAHASHI
}

\begin{abstract}
The purpose of this paper is to clarify the following two points. First point is the indoor air temperature and humidity fluctuation under an optimal operation of heat source system. Second is the effect of the system composition ( heat source equipment capacity ratio ) on the optimization results. Method for the optimization is applied to the hybrid energy source system with thermal storage tank of a middle scale office building on a certain summer day. The results are as follows : 1)the suitable change of the room temperature is calculated automatically by optimization process, so there is possibility of realizing effective energy conservation etc. by more active control of the temperature, 2)the relation between heat source equipment capacity and building heat load influences its suitable ratio, and the ratio influences the achievement degree of the optimal operation effect considerably, 3)according to a trial calculation, it is surmised that the system with a few heat source equipment using various energy is advantageous for pursuing energy conservation etc.
\end{abstract}

Keywords : Optimal operation, Hybrid energy source system with thermal storage tank, Indoor air temperature and humidity fluctuation, Heat source equipment capacity ratio

最適運転計画, 複合熱源蓄熱システム, 室温湿度変動, 熱源装置容量比

1.はじめに

例えば，蓄熱槽などの熱的挙動の時間遅れが無視できない要素を もつ空調システムの省エネ的な運用を考える場合，期間積算エネル ギー消費量を目的関数とした沉関数において，その最小化を図るよ うなダイナミックな最適化が必要になる。空調システムの最適運転 計画に関するこれまでの研究 122)では，その最適化手法に動的計画 法を利用していることが多いが，状態变数や操作変数の次元数が多 くなると計算量が爆発的に増加し，実際的な空調システムへの適用

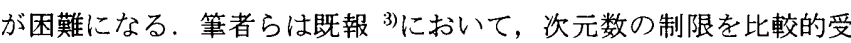
けにくい逐次パラメータ変化法を最適化手法に取り上げ，それを実 在建物に導入されている複合熱源蓄熱システムに適用し, 省エネル ギーや電力負荷平淮化などを目的とした運転計画の最適化効果につ いて明らかにしたが，この最適化手法も目的関数における多峰性へ の対応や探査出発点の設定の難しさに問題を残している.

一方, これまでの研究の延長上に予想される課題に，建物系，空 調系, 搬送系, 熱源系を含むトータルシステムへの適用㧒張とシス テム設計へのフィードバックがあげられる. 従来, 熱源機器が処理 すべき熱量を実測や計算で別途求めておき，それを入力とする熱源 システムに検討範囲を限定する場合が多い，本来，室温湿度は空調
システムの運転結果として実現する状態量と捉えられるので, それ らを最適化計算の状態変数とし, 設定室温などは拘束条件として扱 うことで，躯体蓄熱システム 4 )らにみられる予泠・予熱の概念も含 めた室温湿度のより柔軟な検討が可能となる，また，最適運転計画 効果はシステムの構成に大きく依存するので，空調システムの「最 適運転」と「最適設計」を包括した総合的な検討が必要となる.

本報は既報と同様，空調システムの省エネルギーや電力負荷平淮 化を推進する際の「最適化」の有用性を把握することを目的とする もので，最適化計算をトータルシステムに適用する手法的展開を示 して最適運転計画による室温湿度変動を明らかにすると同時に，そ のシステム構成が最適化効果に与える影響についてシミュレーショ ンによる基本的な検討を行っている. ただし，最適化手法の実用上 の限界とトータルシステムという適用範囲の拡大により, 計算期間 を夏季代表日の 1 日に限定せざるを得なかった，また，計算対象 は中規模事務所ビルの複合熱源蓄熱システムを想定したが，システ ム構成のバリエーションもその熱源装置容量比の違いを取り上げた に過ぎない、今後，豊富なシミュレーションを基に「最適化」に対 する一般的な結論を提示することが必要と考えるが, 本報の内容は, 前述した課題への取り組みも視野に入れた研究の初期段階として位

\footnotetext{
*1 九州大学大学院人間環境学研究科 助教授・博士 (“学)

*2 九州大学大学院人間環境学研究科 教授 - 工博

*3 九州大学大学院総合理工学研究科 助教授. 工博

*4 明治大学工学部建築学科 教授・工博

*5 大成建設株 工修
}

Assoc. Prof., Graduate School of Human-Environment Studies, Kyushu Univ., Dr. Eng.

Prof., Graduate School of Human-Environment Studies, Kyushu Univ., Dr. Eng. Assoc. Prof., Interdisciplinary Graduate School of Engineering Sciences, Kyushu Univ., Dr. Eng.

Prof., Dept. of Architecture, Faculty of Engineering, Meiji Univ., Dr. Eng. Taisei Corporation, M. Eng. 
置付けておきたい.

\section{2. 計算モデル}

図-1 に計算モデル概念図を示す，熱源システムモデルとエネル ギー消費量の計算方法については既報と重複するので割愛する.

\section{1 建物系モデル}

室温湿度を最適化計算の状態変数に考える場合, 除去熱量と室温 湿度の因果関係を平易な形でモデル化しておくことが望ましい，本 報では，顕熱と潜熱に分離した式(1)の熱負荷モデルを考えた．記 号は本報末尾を参照頂きたい。

$$
\begin{aligned}
& Q S, t=B \Delta \theta 1(z) \Delta \theta 1, t+\left\{B_{\Delta \theta 2}(z) / A S(z)\right\} \Delta \theta z, t+B_{J}(z) J_{t} \\
& Q_{L, t}=B \Delta \times 1(z) \Delta x 1, t+\left\{B_{\Delta x 2}(z) / A L(z)\right\} \Delta x 2, t \\
& A s(z)=1+a_{1 S} z^{-1}, A L(z)=1+a_{1 L} z^{-1}, \\
& B_{\Delta \theta 1}(z)=b \Delta \theta 10, B_{\Delta x 1}(z)=b \Delta x 10, B J(z)=b J 0, \\
& B_{\Delta \theta 2}(z)=b \Delta \theta 20+b \Delta \theta 21 z^{-1}, B_{\Delta x 2}(x)=b \Delta x 20+b \Delta x 21 z^{-1}
\end{aligned}
$$

図-2，図-3，表-1 に基づいて HASP/ACLD/85016)で計算される 時刻別の熱負荷と室温湿度および外界気象データを熱負荷モデルの 入出力にあてはめ，モデルパラメータをシステム同定手法により推 定する ${ }^{7)}$.さらに, 図-4の室内発熱スケジュールによる熱負荷を別 途計算しておき，それと式(1)による熱負荷を加算して室全体の熱 負荷を算定する.すなわち，ここでの計算条件はモデルパラメータ の同定に必要となる熱負荷モデルの入出カデータを生成するための ものであり, 後述する最適化計算では, 式(1)の熱負荷モデルと室 内発熱による熱負荷および外界気象条件のみが用いられる。その際 には, HASP/ACSS $/ 8502^{8}$ の倍数展開の概念と同様に，この基準階 の熱負荷モデルが他階にもそのまま適用できるとし, 熱源システム 全体の装置容量（表-7 参照）とのバランスを考えて, 建物全体と
して基準階が 8 層あるものと仮定した. 表-2 に同定したパラメー タを示し, 図-5に HASP 計算値と同定した熱負荷モデルによる計 算値を示す。この熱負荷モデルとパラメータの同定精度が適切であ るかについては議論の余地があるが, 図-5 から室内温湿度と熱負 荷に関する HASP 計算值をほぼ再現していると考えられる.

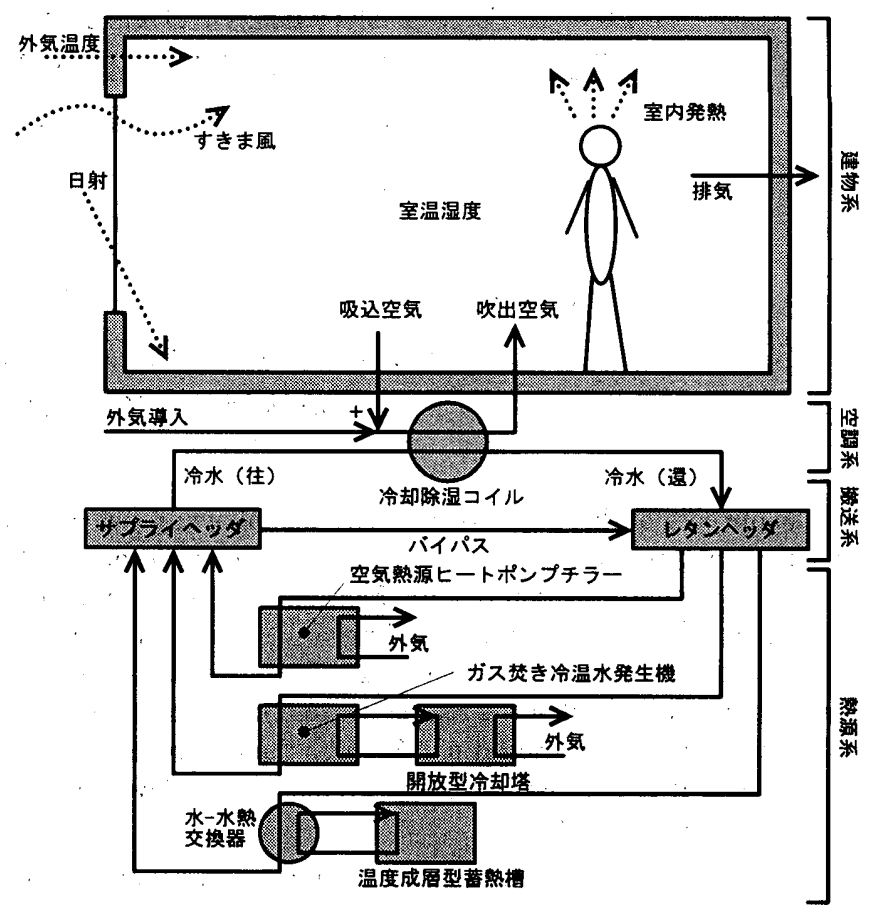

図-1＼cjkstart計算モデルの概念図

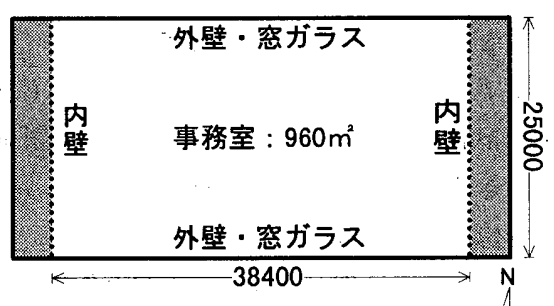

図-2 計算対象室 (単位：mm)

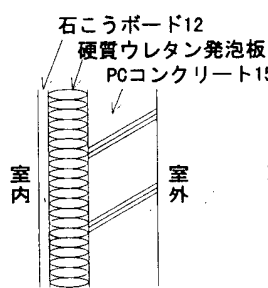

(a) 外壁

隣室 (室内)

\begin{tabular}{|c|c|}
\hline 建物 & : 事務所ビル基淮階 \\
\hline 場所 & : 東京 \\
\hline 気象データ & $\begin{array}{l}: \text { 標淮気象データ } \\
\text { (新東京) }\end{array}$ \\
\hline 設定温湿度 & $: 24^{\circ} \mathrm{C}, 50 \%$ \\
\hline 空調時間帯 & : 平日 9 時 $~ 20$ 時 \\
\hline 室使用時間帯 & : 平日 9 時 $~ 20$ 時 \\
\hline 床面積 & $: 960 \mathrm{~m}^{2}$ \\
\hline 階高 & $: 3.6 \mathrm{~m}$ \\
\hline 天井高 & $: 2.6 \mathrm{~m}$ \\
\hline 外壁面積 & $: 137.3 \mathrm{~m}^{2}$ \\
\hline 内壁面積 & $: 144.0 \mathrm{~m}^{2}$ \\
\hline 空ガラス種類 & : 熱線吸収ガラス \\
\hline 空ガラス厚さ & $: 8 \mathrm{~mm}$ \\
\hline 空ガラス面積 & $: 139.2 \mathrm{~m}^{2}$ \\
\hline ブラインド & :なし \\
\hline すきま風 & $: 0.3$ 回 $/ \mathrm{h}$ \\
\hline 室顕熱容量 & $: 12.6 \mathrm{~kJ} /\left(\mathrm{m}^{2}:{ }^{\circ} \mathrm{C}\right)$ \\
\hline 室潜熱容量 & $: 25.2 \mathrm{~kJ} /\left(\mathrm{m}^{2} \cdot\left(\mathrm{g} / \mathrm{kg}^{\prime}\right)\right)$ \\
\hline 日射吸収率 & 0.8 \\
\hline 長波放射率 & $: 0.9$ \\
\hline 室内発熱量 & :なし \\
\hline 外気導入量 & $: 4.0 \mathrm{~m}^{3} / \mathrm{m}^{2} \mathrm{~h}$ \\
\hline その他 & : 柱・梁は無視する \\
\hline
\end{tabular}

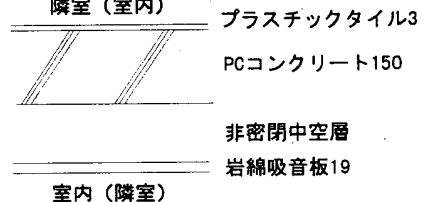

(c) 天井 (床)
表-1 モテルパラメータ同定のための 熱負荷計算条件

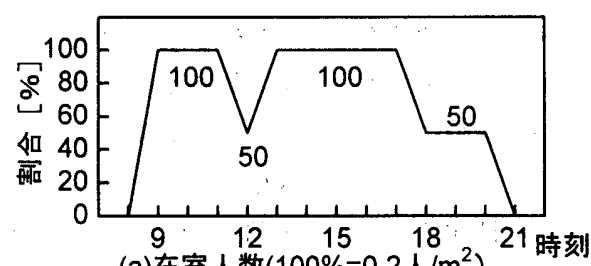

(a)在室人数 $\left(100 \%=0.2 人 / \mathrm{m}^{2}\right)$ 照明 $\left(100 \%=20 \mathrm{~W} / \mathrm{m}^{2}\right)$

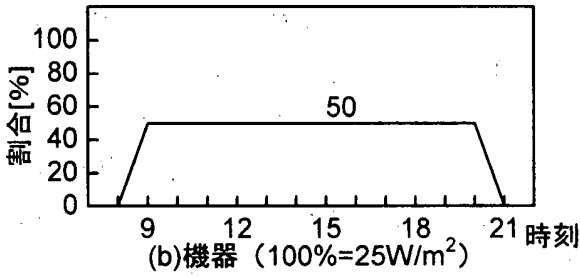

図-4 室内発熱スケジュール

表-2 モデルパラメータの同定結果

\begin{tabular}{ll|ll}
\hline \multicolumn{2}{l|}{ 顕熱モデル } & \multicolumn{2}{|l}{ 潜熱モデル } \\
\hline$a_{1} S \quad:-0.852$ & $a_{1 L}$ & $:-0.749$ \\
$b_{\Delta \theta 10}$ & $:+1.236$ & $b_{\Delta \times 10}$ & $:+1.746$ \\
$b_{J 0}$ & $:+0.132$ & $b_{\Delta x 20}$ & $:-9.572$ \\
$b_{\Delta \theta 20}$ & $:-8.987$ & $b_{\Delta x 21}$ & $:+9.277$ \\
$b_{\Delta \theta 21}$ & $:+8.909$ & & \\
\hline
\end{tabular}

図-3 “壁体仕様（数値は部材厚さ $\mathrm{mm}$,

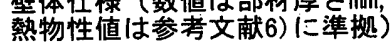




\section{2 空調系モデル}

計算対象室を 1 台のエアハンドリングユニットで行うものとす るが, 加熱コイルや加湿装置, 全熱交換器などは除外し, 泠却除湿 コイルのみをモデル化する.モデル化の際には以下の仮定を設けた. (1)給気ファンとコイル通過におけるリーク風量は見込まない. (2)ファンによる発熱およびダクトからの熱損失は考慮しない.

(3)定風量方式とし，ファンの消費電力はエネルギー消費量の算定に 含まない,

(4)コイルは空気·水の向流型熱交換器を想定する.

(5)コイルにおける乾きと湿りの共存状態を考えない.

コイルにおける空気と冷水の出入口温度の関係を図-6に，コイ ル通過空気の状態変化を図-7 に示す。ここで必要なことは空気と 泠水のコイル入口状態量からそれらのコイル出口状態量を求めるこ とである.まず，コイルのバイパスファクタをコイル仕様と空気流 量から式(2)により求める ${ }^{9}$.

$B=\exp \left\{-\alpha_{o} S_{o} /\left(3.6 \times 10^{6} C_{A} G_{A}\right)\right\}$

次に, コイル出口空気温度をある值 $\bar{T}_{A 2}$ に仮定し, 図-7 から導 かれる式(3)からコイル出口空気湿球温度の仮定値 $\bar{T}_{A S 2}$ を計算する。

$\bar{T}_{A S 2}=\bar{T}_{A 2}-B\left(T_{A 1}-T_{A S 1}\right)$

一方, コイル出入ロ空気のエンタルピー変化と温度による顕熱成 分の変化の比は式(4)で表わせる.

$\xi=\left(H_{A 1}-\bar{H}_{A 2}\right) /\left\{C_{A}\left(T_{A 1}-\bar{T}_{A 2}\right)\right\}$

よって，熱交換における 2 流体間の温度効率はコイル仕様および 空気と冷水の流量から式(5)で求められる ${ }^{10)}$

$\phi=[1-\exp \{-\beta(1-\gamma)\} \backslash[1-\gamma \exp \{-\beta(1-\gamma)\}]$

$\gamma=\xi C_{A} G_{A} / C_{W} G_{W}$

$\beta=K \cdot F \cdot R / \xi C_{A} G_{A}$

さらに，温度効率は空気と冷水の出入口温度からも算定でき，そ れを $\phi^{\prime}$ とすれば式(6)で表わせる。

$\phi^{\prime}=\left(T_{A 1}-\bar{T}_{A 2}\right) /\left(T_{A 1}-T_{W 1}\right)$

本来， $\phi$ と $\phi^{\prime}$ は一致すべきものであるので，両者の差の絶対值 が十分小さくなるようにはじめの仮定 $\bar{T}_{A 2}$ を収束させる， $T_{A 2}$ が
求まれば, コイル出口の空気温度とエンタルピーからその空気の絶 対湿度も計算でき, 必然的にコイル出口冷水温度も求めることがで きる.すなわち, 空気と冷水のコイル入口状態量からコイル出口状 態量が算出できることになる，以上，湿りコイルの場合の計算手順 を述べたが，これは乾きコイルにもそのまま適用でき，その場合は 計算過程で $\xi=1$ となる. コイル外表面熱伝達率については, 乾き コイルと湿りコイルで区別し，以下の実験式 ${ }^{11) に よ り 与 え る . ~}$

$\alpha_{d r y}=0.150 v_{c}^{0.64} \lambda_{A} / v_{A}^{0.64} d e^{0.36}$
$\alpha_{\text {wet }}=0.041 v_{c}^{0.8} \lambda_{A} / v_{A}^{0.8} d_{e}^{0.2}$

冷却除湿コイルの仕様を表-3 に，伝熱係数を図-8 に示す，伝熱 係数はカタログから適当な冷水流速間隔で値を読みとり，その間の 值を直線補間により求めた。
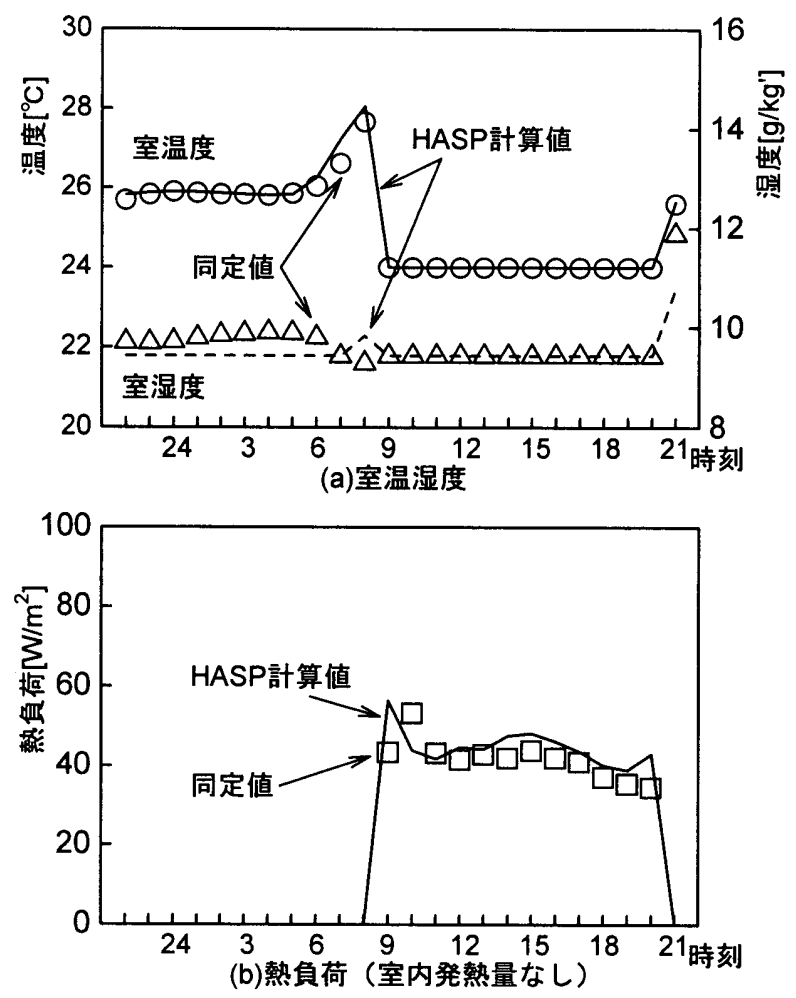

図-5 HASP計算値と同定した熱負荷モデルによる計算値

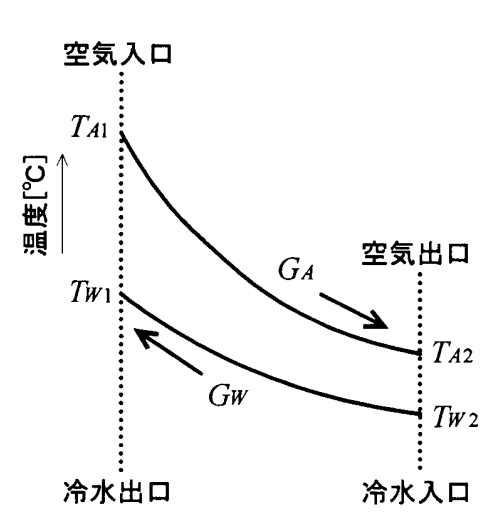

図-6 冷却除湿コイル概念図

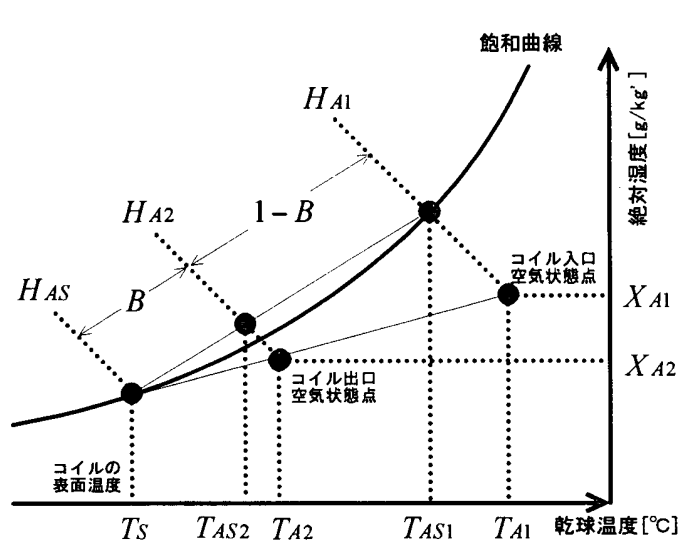

図-7＼cjkstart湿りコイルの空気状態変化

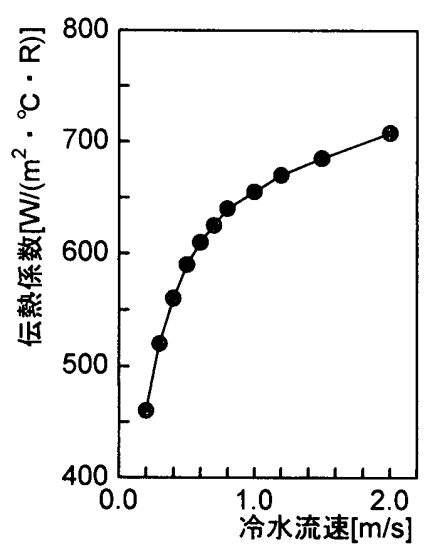

図-8 伝熱係数（冷却時, コイル 正面風速 $2.12 \mathrm{~m} / \mathrm{s}$ ) 


\section{3. 最適化計算の方法}

\section{1 室温湿度とエネルギ一消費量の計算方法}

2.節で述べた建物系モデルと空調系モデルを組み合せて室温湿度 を計算する. 今, 空調時間帯の当該時刻の室温湿度を仮定し, コイ ル入口空気温湿度を室からの還気と外気との混合空気として求める 2.2 節の方法により, 空気と冷水のコイル入口状態量からそれぞれ のコイル出口状態量が算出されるので，コイルの出入口空気温湿度 差と風量により除去する顕・潜熱熱量が求められる。一方，除去熱 量熱負荷モデル（2.1 節式(1)）の左辺に相当するので，両者の除 去熱量が一致するように繰り返し計算により室温湿度を求める。す なわち, 空調時間帯の室温湿度と除去熱量は従来の設定室温湿度と いう概念とは関倸なしに，熱源システムの操作量から決定されるこ とになる. 非空調時間帯の室温湿度は式(1)で除去熱量を 0 とすれ ば良い。

熱源システムのエネルギー消費量は，コイル出口冷水とバイパス 泠水がレタンヘッダで混合し，その泠水が熱源システムへ還ると考 えて，既報に示した方法により計算される.エネルギー消費量には， 熱源機器本体以外に補機電力量, 搬送系ポンプ電力量, 冷却塔ファ ン電力量が含まれるとし, 機器の立ち上がり特性やポンプ発熱, 配 管熱損失については考慮しない，以上，建物系，空調系，搬送系， 熱源系のすべての系について熱的にバランスさせる

\section{2 最適化手法と計算条件}

最適運転計画における操作変数, 操作範囲, 最小操作量を表-4 に，取り上げた運転方式を表-5にまとめる，最適化手法には直接 法の 1 つである逐次パラメータ変化法 ${ }^{3)}$ を用いた。 バイパス流量に 関する操作変数は熱源システムからの冷水流量に対するバイパス流 量の比を考えた。最適化計算における拘束条件は以下の通りである. (1)操作量は設定した操作範囲（表-4）を必ず満たす。

(2)熱源機器やポンプ，ファンの部分負荷率は 1 を越えない.

(3)室使用時間帯は 9〜20 時とする

(4)室使用時間帯の室温は $24^{\circ} \mathrm{C}$ を越えない。

(5)室湿度の拘束条件は設けない，室湿度は成り行きとする.

3.1 節で述べたとおり, 熱源システムの操作量によって室温湿度 が求められるので, 室使用時間帯に室温が $24^{\circ} \mathrm{C}$ を超えるような運 転計画は最適化の過程で自動的に否定される，言い換えれば，非室 使用時閒帯では非空調である必要はなく, その時の室温度は何 ${ }^{\circ} \mathrm{C} か ゙$ 実現されても良いということになる。，一方，一般の事務所ビルでも 夏季冷房時に室の湿度調整まで行うことは希なので，室湿度の拘束 条件は特に設けないこととした。また，室使用時間帯の室温が $24^{\circ} \mathrm{C}$ を超えないという状況は，現在の社会的状況から考えると若干低す ぎるきらいがあるが，既報で取り上げた実在建物の設定室温がほぼ $24^{\circ} \mathrm{C}$ であったこと，本報の熱源システム設計值（表-7）が実在建物 に導入されているものであること，本報の主旨から，まずは検討内 容としてその相対的評価を重視したこと，などによるものである

次に，熱源装置容量比の最適化について，表-6 の計算内容で検 討する.すなわち，表-7 の熱源システム設計值を基準とし，その トータル容量は変化しないものとしてそれぞれの熱源装置容量の全 体に対する比率を変化させる，温度成層型蓄熱槽の槽容積の比率は 空気熱源ヒートポンプチラーの装置容量と同じ比率とし, 冷却塔の 能力比もガス焚き泠温水発生機の装置容量比と同じものを設定した
表-3 冷却除湿コイル仕様

\begin{tabular}{|c|c|c|}
\hline 管配置 : 32 管 6 列 & \multicolumn{2}{|l|}{ フィン } \\
\hline コイル寸法 & \multicolumn{2}{|l|}{ 枚数 $: 522$} \\
\hline 幅 : $1.88 \mathrm{~m}$ & \multicolumn{2}{|c|}{ ピッチ : $0.0034 \mathrm{~m}$} \\
\hline$: 1.67 \mathrm{~m}$ & \multicolumn{2}{|c|}{ 厚さ : :0.0002m } \\
\hline 奥行き：0.26m & \multicolumn{2}{|c|}{ その他 } \\
\hline 管ピッチ & \multicolumn{2}{|l|}{ 吸込風量 } \\
\hline 高さ方向 $\quad: 0.0375 \mathrm{~m}$ & \multicolumn{2}{|l|}{ 外気風量 } \\
\hline 奥行き方向 : $0.0329 \mathrm{~m}$ & \multicolumn{2}{|c|}{ 全熱交換面積 $\quad: 206.2 \mathrm{~m}^{2}$} \\
\hline 管径 & \multicolumn{2}{|c|}{ 正面面積 $\quad: 3.13 \mathrm{~m}^{2}$} \\
\hline 外: $0.0158 \mathrm{~m}$ & 正面風速 & $: 2.12 \mathrm{~m} / \mathrm{s}$ \\
\hline \multirow[t]{2}{*}{ 内 : $0.0146 \mathrm{~m}$} & \multicolumn{2}{|c|}{ 自由流路断面積 : $2.01 \mathrm{~m}^{2}$} \\
\hline & 実風速 & $: 4.20 \mathrm{~m} / \mathrm{s}$ \\
\hline
\end{tabular}

表-4 最適運転計画における操作変数, 操作範团, 最小操作量

\begin{tabular}{|c|c|c|c|}
\hline \multicolumn{2}{|c|}{ 操作変数 } & 操作範囲 & 最小操作量 \\
\hline \multirow{2}{*}{$\begin{array}{l}\text { 空気熱源ヒー } \\
\text { 卜 } \\
\text { ポンプチラー } \\
\end{array}$} & (1)冷水出口温度 & $5 \sim 12^{\circ} \mathrm{C}$ & $1^{\circ} \mathrm{C}$ \\
\hline & (2)冷水流量 & $0,80 \sim 100 \%$ * & $2 \mathrm{~m}^{3} / \mathrm{h}$ \\
\hline 温度成層型 & (3)冷水流量 & $0,80 \sim 100 \%$ * & $2 \mathrm{~m}^{3} / \mathrm{h}$ \\
\hline \multirow[t]{2}{*}{ 開放型冷却塔 } & (4)冷却水流量 & $0,80 \sim 100 \%$ * & $2 \mathrm{~m}^{3} / \mathrm{h}$ \\
\hline & (5)風量 & $0,80 \sim 100 \%$ * & $2000 \mathrm{~m}^{3} / \mathrm{h}$ \\
\hline \multirow{2}{*}{$\begin{array}{l}\text { ガス焚き冷温 } \\
\text { 水発生機 }\end{array}$} & (6)冷水出口温度 & $7 \sim 12^{\circ} \mathrm{C}$ & $1^{\circ} \mathrm{C}$ \\
\hline & (7)冷水流量 & $0,80 \sim 100 \% *$ & $2 \mathrm{~m}^{3} / \mathrm{h}$ \\
\hline \multicolumn{2}{|c|}{ (8)バイパス流量比 } & $0, \quad 0.2 \sim 1.0$ & 0.1 \\
\hline
\end{tabular}

*設計值比（表-7 参照）

\section{表-5 各運転方式}

\begin{tabular}{|c|c|c|c|}
\hline CASE1 & \multicolumn{3}{|c|}{$\begin{array}{l}1 \text { 次換算エネルギー消費量ミニマム運転 : 熱源 } \\
\text { シスデム積算エネル゙ー消費の量の } 1 \text { 次換算 } \\
\text { 値を最小にする運転方式 }\end{array}$} \\
\hline CASE & \multicolumn{3}{|c|}{$\begin{array}{l}\text { 従量料金ミニマム運転 : 熱源システムのエネル } \\
\text { ギー消費量に伴う日積算コストを最小にする運 } \\
\text { 転方式 (従量料金 : ランニングコストから基本 } \\
\text { 料金を差し引いたもの) }\end{array}$} \\
\hline CASE: & \multicolumn{3}{|c|}{$\begin{array}{l}\text { ピーク電力ミニマム運転 : } 8 \text { 時から } 22 \text { 時におけ } \\
\text { るピーク電力を最小にする運転方式 } \\
\end{array}$} \\
\hline \multicolumn{4}{|c|}{ 表-6 検討した熱源装置容量比 } \\
\hline & $\begin{array}{l}\text { ガス焚き泠温水 } \\
\text { 発生機 }\end{array}$ & $\begin{array}{l}\text { 空気熱源ヒート } \\
\text { ポンプチラー }\end{array}$ & $\begin{array}{l}\text { 温度成層型 } \\
\text { 蓄熱槽 }\end{array}$ \\
\hline NO.1 & 0.1 & 0.45 & 0.45 \\
\hline NO.2 & 0.2 & 0.40 & 0.40 \\
\hline NO.3 & 0.3 & 0.35 & 0.35 \\
\hline NO.4 & 0.4 & 0.30 & 0.30 \\
\hline NO.5 & 0.5 & 0.25 & 0.25 \\
\hline NO.6 & 0.6 & 0.20 & 0.20 \\
\hline NO.7 & 0.7 & 0.15 & 0.15 \\
\hline NO.8 & 0.8 & 0.10 & 0.10 \\
\hline NO.9 & 0.9 & 0.05 & 0.05 \\
\hline
\end{tabular}

表-7 熱源システム設計値

1)空気熱源ヒートポンプチラー

冷凍能力: $383 \mathrm{~kW}$, 本体電力 : $104 \mathrm{~kW}$, 補機電力 : $8.4 \mathrm{~kW}$, 冷水流量 : $0.78 \mathrm{~m}^{3} / \mathrm{min}$, ポンプ電力: $3.7 \mathrm{~kW}$, 出口温度 : $5^{\circ} \mathrm{C}$ 2)ガス焚き椧温水発生機

冷凍能力 : $528 \mathrm{~kW}$, ガス消費量 : $105 \mathrm{~m}^{3} / \mathrm{h}$, 補機電力 : $8.6 \mathrm{~kW}$, 冷水流量 : $1.08 \mathrm{~m}^{3} / \mathrm{min}$, 出口温度 : $7^{\circ} \mathrm{C}$

3)温度成層型蓄熱槽

蓄熱槽容量 : $500 \mathrm{~m}^{3}$, 水染 : $1.7 \mathrm{~m}$, 冷水流量 : $0.78 \mathrm{~m}^{3} / \mathrm{min}$, ポンプ電力：(蓄熱時） $3.7 \mathrm{~kW}$ (放熱時) $7.4 \mathrm{~kW}$

4)開放型冷却塔

冷却能力: $971 \mathrm{~kW}$, 冷却水量 : $2.53 \mathrm{~m}^{3} / \mathrm{min}$

風量 : $85440 \mathrm{~m}^{3} / \mathrm{h}$, ポンプ電力 $: 15 \mathrm{~kW}$, ファン電力 : $11 \mathrm{~kW}$ 5)水-水熱交換器

熱交換熱量 : $383 \mathrm{~kW}$, 出入口温度差 : $7^{\circ} \mathrm{C}$ 

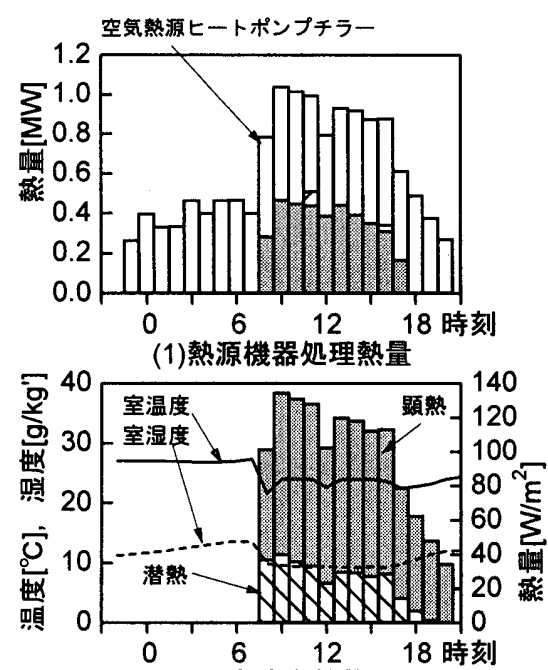

(2)室除去熱量

(a)熱源装置容量比NO.1

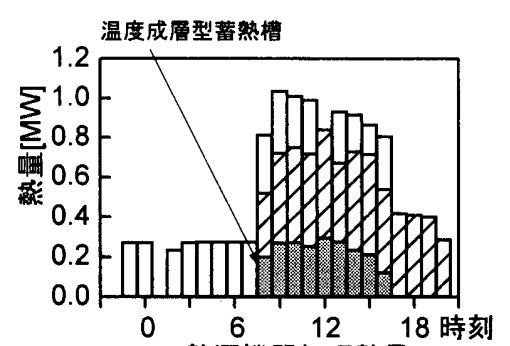

(1)熱源機器処理熱量

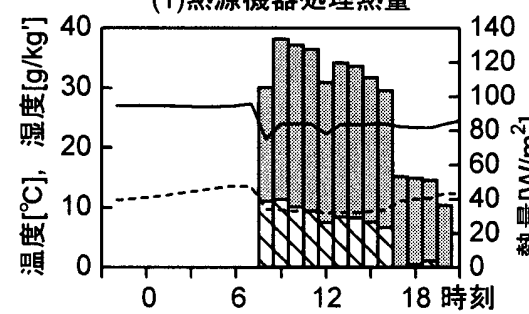

(2)室除去熱量

(b)熱源装置容量比NO.5

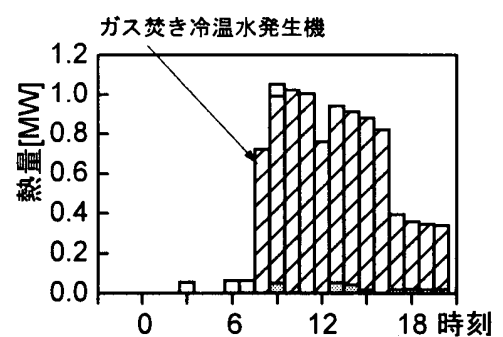

(1)熱源機器処理熱量

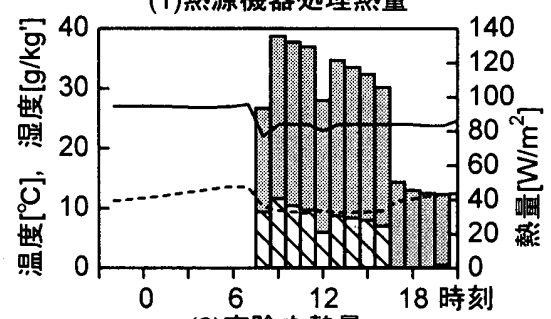

(2)室除去熱量

(c)熱源装置容量比NO.9

図-9＼cjkstart最適運転計画による熱源機器処理熱量および室除去熱量（CASE1でNO.1，NO.5，NO.9の場合）

また，それぞれの熱源機器における冷水流量と補機類の電力量もそ の機器の装置容量比と同じ割合で変化させた．熱源システムのエネ ルギー消費量を計算するには，ある冷凍能力における定格電力や定 格ガス消費量のデータが必要となるが, 熱源機器に関するカタログ データを整理したところそれらの定格值はほぼ冷凍能力に比例する 值となっていたので, ここではこれらの值が統計処理によって得ら れた回帰直線に従うものとした。

\section{4. 最適運転計画における室温湿度変動とシステム構成が最適化効 果に与える影響}

本報の主な内容は, 熱源システムの運転計画を最適化した場合の 室温湿度変動について明らかにし, そのシステム構成が最適化効果 に与える影響について検討するものである．最終的には通年にわた る期間評価が必要になるが, 本報のトータルシステムについて最適 化計算を実行するには, 現段階ではかなりの計算時間と計算量が要 求される. また, 最適化計算は 1 日単位で行っており, 前日最終 時刻の状態值に当日の最適操作量や目的関数が直接影響を受ける.

よって, 数日間の比較的短い期間評価を行っても算定される結果が 曖昧なものとなりがちで最適化に対する明確な検討が行い難い，そ こで, 本報では夏季の代表的な 1 日に対して検討を行うものとし, 既報の実測データを参考にして計算上の初期値（前日最終時刻の状 態值）を以下のように与えた。

(1)室温湿度は $27^{\circ} \mathrm{C}, 50 \%$ とする.

(2)蓄熱槽温度分布は鉛直方向一様に $13^{\circ} \mathrm{C}$ とする.

\section{1 室温湿度変動}

運転方式が CASE1 で，熱源装置容量比が NO.1, NO.5, NO.9 の場合の熱源機器処理熱量および室除去熱量を図-9に，その時の 室温湿度変動（NO.1〜NO.9）を図-10 に代表的に示す．既報でも 示したように, 最適化された熱源機器の運転計画は各運転方式で異 なるが, その際に実現される室温湿度变動の違いは運転方式や熱源 機器装置容量比に大きく依存するものではなかった。

まず，共通している特徴は，室使用時間帯の室温が $24^{\circ} \mathrm{C}$ 以下と いう拘束条件を遵守しつつできるだけ $24^{\circ} \mathrm{C}$ に近い室温を維持する

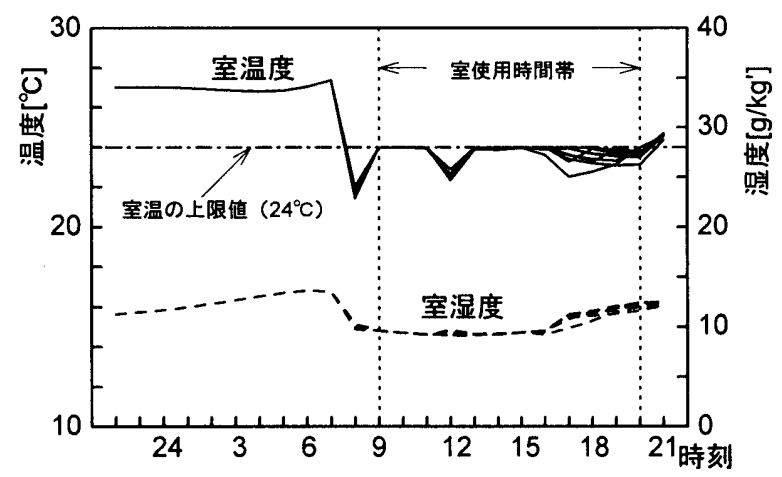

図-10 室温湿度変動（CASE1，NO.1 NO.9の場合）

という点があげられる．これは，1 次換算エネルギー消費量を小さ くするために熱源機器の処理熱量を最小限にするという運転が選択 された結果と理解できる. 一方, 8 時, 12 時, $15 \sim 20$ 時の室温が $21 \sim 23^{\circ} \mathrm{C}$ と低い值を示しているが，8 時という時刻は室使用時間 帯ではないので, 室温に関する拘束条件はなんら課されていない。

8 時という時刻のみを考えれば, 熱源機器は停止し, 室温が自然室 温となることも予想されるが，1 日単位の最適化を考えたときには， むしろ室内発熱量がなくて熱負荷の小さな時刻にある程度室を冷や しておき, 建物躯体の蓄熱負荷を利用してその時刻以降の熱源機器 の処理熱量を小さくした方が結果的に 1 次換算エネルギー消費量 を小さくできるということを示している．この運転は空調開始時ま でに設定室温にするという通常の予泠運転とも異なり, 最適化計算 の過程で適切な運転方法が自動的に選択されたと考えられる. 12 時の室温低下もこれと同様に解釈できる．また，15２0 時の室温 低下は, 熱源機器を停止させれば室温が $24^{\circ} \mathrm{C}$ を超えてしまい，最 小限に熱源機器を稼動させても，この時間帯の熱負荷が小さいため に結果的に室温低下が避けられなかったと推察される.

12 時や 15 20 時の運転計画については, これらの時間帯が室 使用時間帯であることを考慮すると室温が低すぎるという評価にも なり，1 次換算エネルギー消費量を小さくする代償として室の快適 性が損なわれていると考察される。これは，室温の拘束条件に下限 

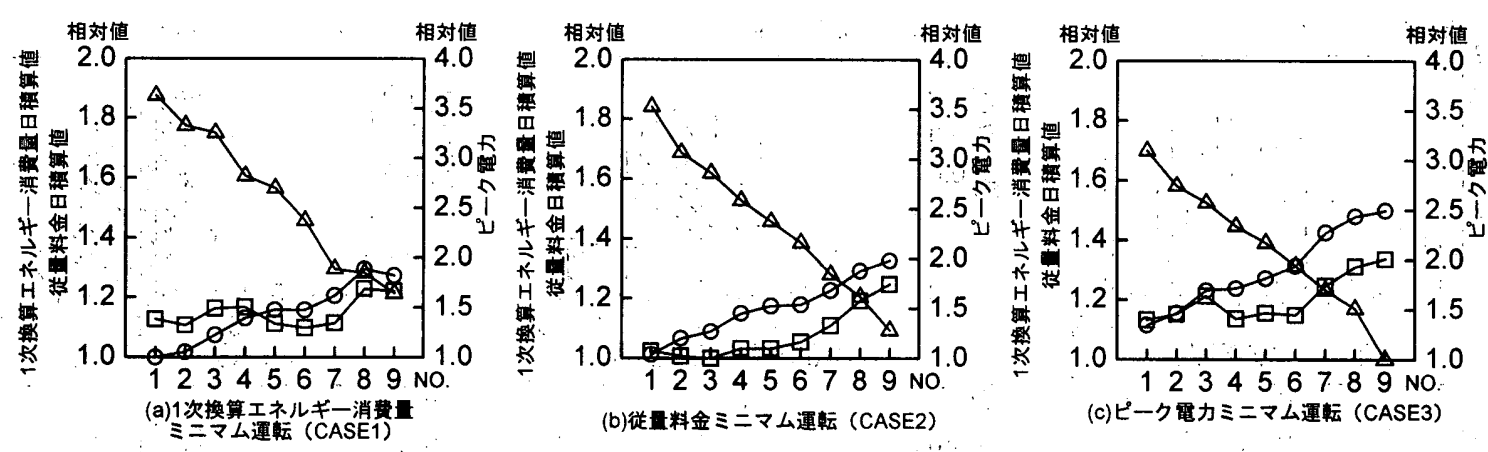

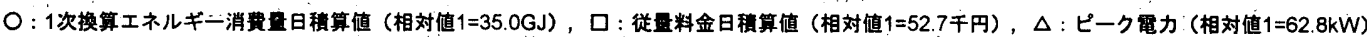
図-11 熱源装置容量比と目的関数の相対値
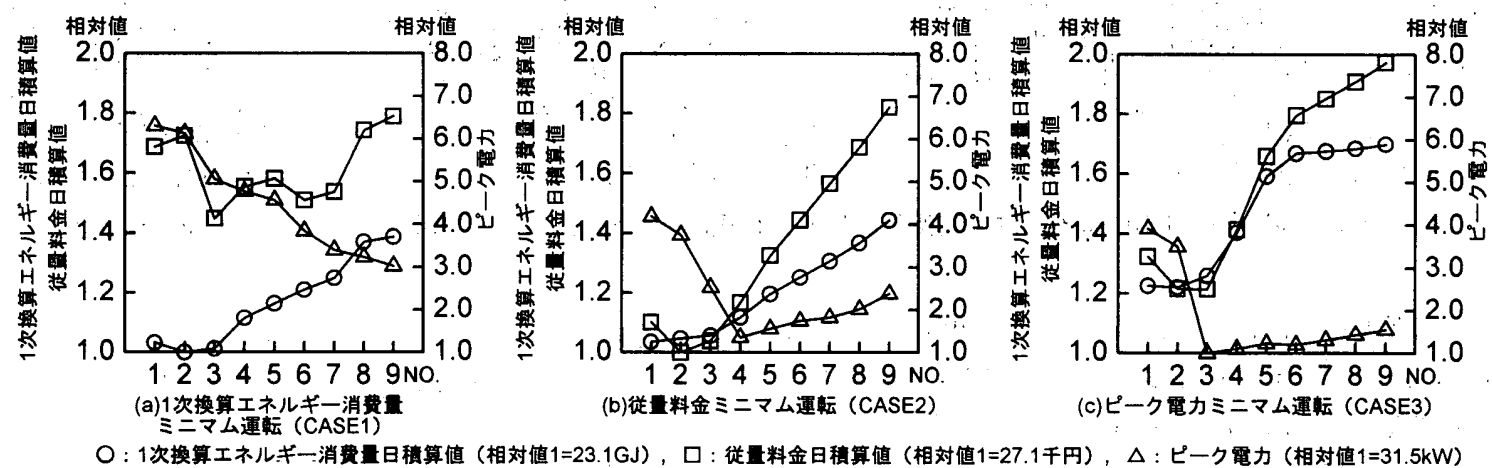

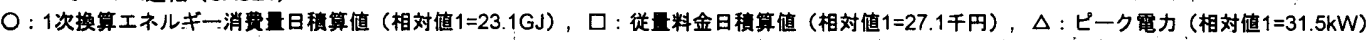
図-12 熱源装置容量比と目的関数の相対値（図-11よりも小さい熱負荷を想定した場合）

値を設けていないことに起因するものであるが，上限值と下限值の 両方を指定すると最適化手法である逐次パラメータ変化法の探查出 発点の設定が非常に難しくなる．この点は逐次パラメータ変化法の 短所であり, 今後, 改良を加えていく必要がある.いずれにしても, 室温湿度を従来の設定室温湿度のように固定的な条件で与えるので はなく，それらをより積極的に制御することによって省エネルギー といった目的が効果的に実現できる可能性がある.

\section{2 熱源装置容量比と目的関数の評洒}

図-11 に各運転方式の熱源装置容量比（NO.1～NO.9）における 1 次換算エネルギー消費量日積算値, 従量料金日積算値, ピーク電 力を示す. 図-11(a)(b)(c)の縦軸は，1 次換算エネルギー消費量日積 算値, 従量料金日積算值; ピーク電力それぞれについて最も值が小 さいものを 1 とし，それに対する相対值を表示している. 図中マ 一ク説明文の（）内数值は相対値 1 のときの絶対值である.

図-11 をみると，運転計画の最適化を行っても，熱源装置容量比 の違いによって，1 次換算エネルギー消費量日積算值, 従量料金日 積算值，ピーク電力はそれぞれ 1.0〜 1.2 倍, $1.0 \sim 1.3$ 倍, $1.0 \sim 3.0$ 倍程度の影響を受ける。特に, ピーク電力については熱源装置容量 比の影響が大きい，そして，いずれの運転方式でも，空気熱源ヒ一 トポンプチラーと蓄熱槽が支配的であればあるほど 1 次換算エネ ルギー消費量日積算値と従量料金日積算值は小さくなり，逆に，ガ 不焚き泠温水発生機が支配的であればピーク電力は小さくなる傾向 がある．従量料金の低減効果は蓄熱システムの割合が大きいほど有 利であり, 電力負荷平淮化の効果はガズ焚き椧温水発生機の割合が 大きいほど有利であるというこの結果は，「最適設計」なしに先験 的なものから予想できる極めて当然のことではあるが，これが夏季 代表日だけではなく期間的な評価においても当てはまるとは限らな
い. 建物で発生する熱負荷と熱源システム全体の装置容量をバラシ スさせるため,ここでは建物基準階が 8 層あるものとして計算し ており, いずれの運転方式, 熱源機器装置容量比においても, 各熱 源機器は全負荷運転に近い運転を行っている，すなわち，熱源機器 そのものがもつエネルギー消費特性に依存するところが大きく，運 転計画の自由度が少ない状況を示していると考察される.

そこで，概略ではあるが，基淮階数の 8 層を 5 層に変更し，仮 想的に熱負荷の小さい日を想定して, 同様の計算を行ってみた（図 -12). 図-12 の場合, 1 次換算エネルギー消費量や従量料金, ピー ク電力に明らかな谷底が見られる．これは熱負荷が小さくなったこ とで熱源機器が処理すべき熱量も小さくなり, 例えば熱源装置容量 比によっては空気熱源ヒートポンプチラーを運転しなくても蓄熱槽 とガス焚き冷温水発生機のみで対応できるような場合がでてきたこ とによると考えられる．この場合は，省エネルギーや従量料金の低 减を図るのであれば NO.1〜NO.3 が適切であり, 電力負荷平淮化 を目的とすればNO.1，NO2 は避けた方が良いということになる.

図-11 と図-12 より, 最適運転計画による効果を有効に発揮し得 る熱源装置容量比は建物熱負荷の大きさに左右され, システム構成 を最適化する際の期間評価の必要性が再認識された。本節の内容は, 非常に限られた試算の域をでないものであるが，泠房期間中に最大 負荷が生じる日数は,一般にはそれほど多くないこどを考慮すれば, 除去熱量のすべてを 1 種類の熱源機器で賄うシステムよりも，異 種エネルギー源による複数の熱源機器を目的に応じてバランス良く 設置したシステムの方が, 省エネルギーやランニングコストの低減, 電力負荷平準化を総合的に推進していくことができると推察される.

5. まとめ

本報では，建物系を含むトータルジステムに最適化手法を適用し， 
熱源システムの運転計画を最適化した際の室温湿度変動とそのシス テム構成が最適化効果に与える影響に関して, 中規模事務所ビルに おける複合熱源蓄熱システムの夏季代表日を例に基礎的検討を行っ た．本報で得られた主な知見を以下に示す。

(1)最適化計算を熱源系だけではなく建物系，空調系，搬送系を含 んだトータルシステムへ適用する際の手法を示した。

(2)熱源システムの最適運転計画により, 室使用開始直前の 8 時と 室内発熱量の小さい 12 時には室を冷やし込む運転が選択された。 一般的な事務所では空調時の室温目標值を固定的に扱うことが多い が，それらをより積極的に制御することで省エネルギーといった目 的が効果的に実現できる可能性がある.

(3)複合熱源蓄熱システムで夏季代表日の場合, 各運転方式の最適 運転計画効果が熱源装置容量比によって受ける影響は, 1 次換算エ ネルギー消費量日積算值, 従量料金日積算值, ピーク電力で約 1.0 $\sim 1.2$ 倍, $1.0 \sim 1.3$ 倍, $1.0 \sim 3.0$ 倍程度となる. システムの構成内 容が運転計画の最適化効果に与える影響は大きい。

(4)運転計画の最適化効果が十分に得られる熱源装置容量比は建物 熱負荷の大きさに左右され，最適設計における期間評価の重要性が 確認されたが，本報の試算によれば，異種エネルギーによる複数の 熱源機器を目的に応じてバランス良く設置したシステムが省エネル ギーや電力負荷平準化の総合的推進に有利であることが推察できた. (5)省エネルギーや電力負荷平淮化を推進するには, 空調システム の運用管理だけでなく, 設定室温の与え方やシステム構成にも慎重 な配慮が必要であり，これらの検討に「最適化」という手段が十分 有用であるとの見通しを得た。将来的には工学的判断に基づく実用 的な最適化手法の開発が不可欠である.

\section{記号}

式(1) $/ z$ : 遅延演算子, $a_{1 S,} a_{1 L}, b_{\Delta \theta 10}, b \Delta \times 10, b J 0, b \Delta \theta 20, b \Delta \theta 21, b \Delta \times 20$, $b \Delta x 21$ : 熱負荷モデルパラメータ, $t$ : 時間 $[\mathrm{h}], Q s, t, Q_{L, t}:$ 顕熱・潜熱 負荷（室内発熱なし） $\left[\mathrm{W} / \mathrm{m}^{2}\right], \Delta \theta_{1, t}$ : 外気温度と基淮温度の差 $\left[{ }^{\circ} \mathrm{C}\right]$, $\Delta x_{1, t}$ : 外気湿度と基淮湿度の差 $[\mathrm{g} / \mathrm{kg}], \Delta \theta_{2, t}$ : 室内温度と基淮温度の差 $\left.{ }^{\circ} \mathrm{C}\right]$, $\Delta x_{2, t}$ : 室内湿度と基淮湿度の差 $[\mathrm{g} / \mathrm{kg}], J_{t}$ : 鉛直面日射量 $\left[\mathrm{W} / \mathrm{m}^{2}\right]$ 式(2) $/ B$ : コイルのバイパスファクタ, $G_{A}$ : コイル通過空気流量 $\left[\mathrm{m}^{3} / \mathrm{h}\right]$, $\alpha_{o}:$ コイル外表面熱伝達率 $\left[\mathrm{W} /\left(\mathrm{m}^{2} \cdot{ }^{\circ} \mathrm{C}\right)\right], S_{o}:$ コイル全熱交換面積 $\left[\mathrm{m}^{2}\right]$, $C_{A}:$ 空気容積比熱 $\left[\mathrm{kJ} /\left(\mathrm{m}^{3 .}{ }^{\circ} \mathrm{C}\right)\right] \quad\left(C_{A}=1.21\right)$

式(3)/ $T_{A 1}, T_{A 2}$ : コイル入口・出口空気温度 $\left[{ }^{\circ} \mathrm{C}\right], T_{A S 1}, T_{A S 2}$ : コイル入 口・出口空気湿球温度 [ $\left.{ }^{\circ} \mathrm{C}\right]$

式(4)／：コイル出入口空気のエンタルピー変化と温度による顕熱成分の 変化の比, $H_{A 1}, H_{A 2}$ : コイル入口・出口空気エンタルピー $\left[\mathrm{kJ} / \mathrm{m}^{3}\right]$
式(5) $/ \phi:$ 温度効率, $C W$ : 冷水容積比熱 $\left[\mathrm{kJ} /\left(\mathrm{m}^{3} \cdot{ }^{\circ} \mathrm{C}\right)\right] \quad(C W=4186)$, $G W$ : 冷水流量 $\left[\mathrm{m}^{3} / \mathrm{h}\right], K$ : 単位コイル正面面積, 単位コイル列数あたり の伝熱俰数 $\left[\mathrm{W} /\left(\mathrm{m}^{2} \cdot{ }^{\circ} \mathrm{C} \cdot R\right)\right], \quad F$ : コイル正面面積 $\left[\mathrm{m}^{2}\right], \quad R$ : コイル列数 式(6) $/ T W 1, T W_{2}:$ :コイル入口・出口冷水温度 $\left[{ }^{\circ} \mathrm{C}\right]$

式(7) $/ \alpha_{d r y}, \alpha_{w e t}$ : 乾きコイル・湿りコイルの外表面熱伝達率 $\left[\mathrm{W} /\left(\mathrm{m}^{2} \cdot{ }^{\circ} \mathrm{C}\right)\right.$ ], $v_{c}$ : 実風速 $[\mathrm{m} / \mathrm{s}]\left(v_{c}=G_{A} / S_{c}\right), \lambda_{A}:$ 空気熱伝導率 $\left[\mathrm{W} /\left(\mathrm{m} \cdot{ }^{\circ} \mathrm{C}\right)\right]$ $\left(\lambda_{A}=0.0221\right), v_{A}:$ 空気動粘性係数 $\left[\mathrm{m}^{2} / \mathrm{s}\right] \quad\left(v_{A}=0.156 \times 10^{-4}\right), d_{e}$ : コイル相当直径 $[\mathrm{m}]\left(d_{e}=4 S_{c} p / S_{o}\right), S_{c}$ : コイル自由流路断面積 $\left[\mathrm{m}^{2}\right]$, $p:$ コイル管奥行き方向ピッチ $[\mathrm{m}]$

\section{参考文献}

1)長井達夫，松尾 陽 : 躯体の熱容量を考慮した空調連転における動的最適 化手法に関する研究，空気調和・衛生工学会学術講演会講演論文集, pp. 257 ２60，1994年

2)Braun,J.E. : A Comparison of Chiller-Priority, Storage-Priority, and Optimal Contorol of an Ice-Storage System, ASHRAE Transaction, Vol.98, pp.893 902, 1992

3)赤司泰義, 渡辺俊行, 龍 有二, 松尾 陽, 高橋淳一 : 複合熱源蓄熱シス テムの運転計画における最適化効果について，日本建築学会計画系論文集， No.499, pp.27〜34，1997年

4)射場本忠彦，坪田祐二，渡辺 聡，八乙女镢, 近藤 武: 潜熱壁体による 躯体蓄熱システムに関する研究（住宅における冷房ピークカット運転の可能 性の検討), 空気調和·衛生工学会学術講演会講演論文集, pp.993 996, 1995 年

5)Ryu,Y., Watanabe,T., Yoshitake,Y., Akashi,Y., Hashimoto,M. : A Study on Environmental Characteristics of the Air-conditioning System with Floor Thermal Storage, Proceedings of 7th International Conference on Thermal Energy Storage, pp.361 366, 1997

6)（社）建築設備技術者協会 : HASP/ACLD/8501 解説，1986 年 7)赤司泰義，松尾 陽，永田明寛，渡边俊行 : 建物の熱負荷と熱的特性の同 定に関する研究，日本建築学会計画系論文報告集，No.450, pp.19〜27, 1993 年

8）（社）建築設備技術者協会 : 空調システム標準シミュレーションプログラ ムHASP/ACSS/8502 プログラム解説書, 1986 年 9)井上宇市 : 改訂 3 版 空気調和ハンドブック，丸善，1985 年 10）（社）日本機械学会 : 伝熱工学資料（改訂第 3 版，1975 年 11)石野久彌，郡 公子 : 冷却コイルの詳細熱解析とその基本的応用に関す る研究，空気調和・衛生工学会論文集，No.23，pp.57-69，1983 年

（1998年4月27日原稿受理，1998年11月27日採用決定） 